\title{
IMPACT, a Coupled Tropospheric/Stratospheric Chemistry Model: Analysis and Comparison of Results to Observations
}

D. Rotman, et al

\section{December 11, 2000}

Lawrence

Livermore

National

Laboratory

U.S. Department of Energy

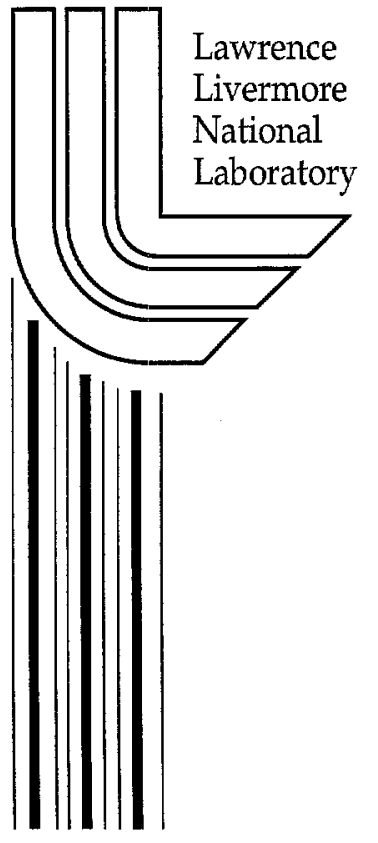




\section{DISCLAIMER}

This document was prepared as an account of work sponsored by an agency of the United States Government. Neither the United States Government nor the University of California nor any of their employees, makes any warranty, express or implied, or assumes any legal liability or responsibility for the accuracy, completeness, or usefulness of any information, apparatus, product, or process disclosed, or represents that its use would not infringe privately owned rights. Reference herein to any specific commercial product, process, or service by trade name, trademark, manufacturer, or otherwise, does not necessarily constitute or imply its endorsement, recommendation, or favoring by the United States Government or the University of California. The views and opinions of authors expressed herein do not necessarily state or reflect those of the United States Government or the University of California, and shall not be used for advertising or product endorsement purposes.

This work was performed under the auspices of the U. S. Department of Energy by the University of California, Lawrence Livermore National Laboratory under Contract No. W-7405-Eng-48.

This report has been reproduced directly from the best available copy.

Available electronically at http://www.doc.gov/bridge

Available for a processing fee to U.S. Department of Energy

And its contractors in paper from

U.S. Department of Energy

Office of Scientific and Technical Information

P.O. Box 62

Oak Ridge, TN 37831-0062

Telephone: (865) 576-8401

Facsimile: (865) 576-5728

E-mail: reports@adonis.osti.gov

Available for the sale to the public from

U.S. Department of Commerce

National Technical Information Service

5285 Port Royal Road

Springfield, VA 22161

Telephone: (800) 553-6847

Facsimile: (703) 605-6900

E-mail: orders@ntis.fedworld.gov

Online ordering: http://www.ntis.gov/ordering.htm

\section{$\mathrm{OR}$}

Lawrence Livermore National Laboratory Technical Information Department's Digital Library

http://www.llnl.gov/tid/Library.html 
IMPACT, a coupled tropospheric/stratospheric chemistry model:

Analysis and comparison of results to observations

Rotman, D., C. Atherton, D. Bergmann, P. Cameron-Smith, C. Chuang, P. Connell, J. Dignon, A. Franz, K. Grant, A. Mirin, C. Molenkamp, and J. Tannahill

\section{LLNL}

We have conducted multi-year simulations describing the distributions of important chemical species in both the troposphere and stratosphere using the LLNL IMPACT atmospheric chemistry model. Simulations have been completed using input meteorological data from both a general circulation model (NCAR MACCM3, Middle Atmospheric Community Climate Model Version 3) and analyzed fields (NASA Data Assimilation Office, STRATF product). IMPACT includes modules describing tropospheric and stratospheric processes and emissions to determine species distributions from the surface to approximately 70 kilometers in altitude. We compare results of these simulations with both long term and short term observational data including surface measurements, vertical profiles and others. We contrast the model's ability to simulate important photochemical cycles ( $\mathrm{CO} / \mathrm{CH} 4 / \mathrm{NMHC} / \mathrm{NO} / \mathrm{OH} / \mathrm{O} 3$, etc) using both input meteorological datasets. In addition, IMPACT simulations driven with analyzed data are compared to ground based and aircraft campaigns.

This work was performed under the auspices of the U.S. DOE by UC, LLNL under contract no. W-7405-Eng-48. 